\title{
Komposisi Proksimat, Kandungan Kalsium dan Karakteristik Organoleptik Snack bar Pisang Raja dan Kacang Kedelai Sebagai Alternatif Makanan Selingan Balita \\ Proximate Composition, Calcium Content and Organoleptic Properties of Snack bar from Banana and Soybean as Alternative Snack for Toddler
}

\author{
Rohmatul Ummah, Enny Probosari, Gemala Anjani dan Diana Nur Afifah*
}

Departemen Ilmu Gizi, Fakultas Kedokteran, Universitas Diponegoro

Jalan Prof. H. Soedarto, SH, Tembalang, Semarang 50275

\section{Riwayat Naskah:}

Diterima: Mei 2020

Direvisi: Desember 2020

Disetujui: Desember 2020
ABSTRAK: Asupan gizi makro dan mikro yang tidak terpenuhi dapat meningkatkan risiko terjadinya stunting balita. Makanan selingan perlu diberikan untuk membantu memenuhi kebutuhan gizi balita. Pisang raja dan kacang kedelai mengandung tinggi protein dan kalsium sehingga pembuatan snack bar pisang raja dan kacang kedelai diharapkan menjadi makanan selingan balita dengan kandungan gizi dan karakteristik organoleptik yang baik. Penelitian ini adalah penelitian eksperimental rancangan acak lengkap satu faktor dengan perbandingan variasi pisang raja dan kacang kedelai F1(9:1), F2(4:1) dan F3 (7:3). Analisis statistik komposisi proksimat, kandungan kalsium dan karakteristik organoleptik berdistribusi normal diuji dengan One Way ANOVA serta uji lanjut Duncan dan apabila berdistribusi tidak normal diuji dengan Kruskall-Wallis serta uji lanjut Mann-Whitney. Formula terbaik menggunakan metode De Garmo. Hasil penelitian menunjukkan bahwa terdapat pengaruh formulasi pisang raja dan kacang kedelai terhadap kandungan protein, lemak, karbohidrat, air, abu, serat pangan, dan kalsium $(p<0,05)$. Karakteristik organoleptik pada parameter rasa $(p=0,028)$ dan tekstur $(p=0,017)$ juga menunjukkan ada perbedaan yang signifikan. Formula snack bar terbaik yang dapat memenuhi kebutuhan makanan selingan pada balita adalah snack bar F2 dengan kandungan lemak 4 g, karbohidrat 18,08 g, serat pangan 3,27 g dan kalsium $617 \mathrm{mg}$.

Kata kunci: kacang kedelai, organoleptik, pisang raja, snack bar, zat gizi

ABSTRACT: Inadequate macro and micronutrients intake can increase the risk of toddler stunting. A snack needs to be provided to help meet the nutritional needs of toddlers. Banana and soybeans contain high protein and calcium, so that the manufacture of snack bar banana and soybeans is expected to be a snack bar for toddlers with good nutritional content and organoleptic properties. This study was one-factor completely randomized experimental study with ratio banana and soybeans snackbars F1 (9:1), F2 (4:1) and F3 (7:3). Statistic analysis for proximate composition, calcium content and organoleptic properties with normal distribution was tested using one way anova test followed by duncan's posthoc test and if abnormal distribution was tested using the kruskal wallis test followed by mann-whitney's posthoc test. The best formulation using De Garmo method. The results showed that there was an influence of the formulation of banana and soybean on the content of proximate and calcium $(p<0.05)$. Organoleptic properties in the parameter of taste $(p=0.028)$ dan texture $(p=0.017)$ showed a significant difference. F2 is the best snack bar formula which contains fat $4 \mathrm{~g}$, carbohydrate $18.08 \mathrm{~g}$, fiber $3.27 \mathrm{~g}$, calcium $617 \mathrm{mg}$ and can meet the nutritional needs of snack foods in toddler.

Keywords: soybeans, organoleptic, banana, snack bar, nutrient

\footnotetext{
Kontributor utama

Email korespondensi: d.nurafifah.dna@fk.undip.ac.id
} 


\section{Pendahuluan}

Kurangnya konsumsi pangan dengan gizi seimbang pada anak berpengaruh terhadap tingkat pencapaian pertumbuhan pada masa berikutnya (Esfarjani, Roustee, Mohammadi-Nasrabadi, \& Esmaillzadeh, 2013). Asupan gizi yang tidak terpenuhi akan menyebabkan kekurangan gizi pada anak dan dapat mengakibatkan daya tangkapnya berkurang, anak kurang aktif bergerak, penurunan konsentrasi belajar, daya tahan tubuh lemah serta berpostur pendek/stunting akibat pertumbuhan yang tidak optimal (Esfarjani et al., 2013). Stunting/pendek merupakan salah satu masalah gizi kronis pada anak yang sekarang masih banyak terjadi, ditandai dengan panjang atau tinggi badan kurang dibandingkan dengan usianya (Kementerian Kesehatan RI, 2018). Dikatakan stunting jika panjang atau tinggi badan menurut usianya di bawah negatif 2 standar deviasi dari median standar pertumbuhan anak WHO (Kementerian Kesehatan RI, 2010). Pada tahun 2005-2017 rata-rata prevalensi balita stunting di Indonesia adalah 36,4 \%. Data Pemantauan Status Gizi (PSG) Ditjen Kesehatan Masyarakat menyebutkan pada tahun 2017 prevalensi balita stunting meningkat 2,1\% dari tahun 2016 menjadi 29,6 \%. Di Jawa Tengah prevalensi stunting tahun 2017 sebesar 28,5 \% (Kementerian Kesehatan RI, 2018). Berdasarkan data Riskesdas 2018, prevalensi stunting tahun 2018 yaitu sebesar 30,8 \%. Persentase ini masih tergolong tinggi karena mengacu dari WHO, prevalensi stunting seharusnya kurang dari $20 \%$. Dampak dari stunting dapat meningkatkan kejadian penyakit dan kematian pada anak, meningkatkan biaya kesehatan, mempengaruhi tumbuh kembang anak yang tidak optimal, postur tubuh pendek saat dewasa, menurunkan kualitas kesehatan reproduksi, meningkatkan risiko obesitas dan penyakit lainnya, menurunkan performa belajar dan produktivitas kerja (Kementerian Kesehatan RI, 2018).

Asupan gizi adalah salah satu faktor yang secara langsung mempengaruhi kejadian stunting. Penelitian sebelumnya menunjukkan bahwa pada balita stunting memiliki asupan kategori kurang pada protein, lemak dan karbohidrat, sedangkan balita non-stunting memiliki asupan kategori cukup. Balita dengan asupan protein, lemak dan karbohidrat yang kurang memiliki risiko 1,7 kali lebih besar mengalami stunting (Sari, Juffrie, Nurani, \& Sitaresmi, 2016). Kalsium merupakan salah satu dari zat gizi mikro penting dalam mencegah kejadian stunting pada anak. Pada proses pertumbuhan, kalsium dibutuhkan dalam proses mineralisasi tulang yang meningkat. Ketidakcukupan asupan kalsium selama proses pertumbuhan ini dapat mengakibatkan disfungsi osteoblast, mineralisasi matriks deposit pada tulang baru berkurang serta apabila kandungan kalsium dalam tulang kurang dari 50\% mempengaruhi pertumbuhan linier (Persagi, 2017).

Pisang merupakan buah yang diketahui memiliki kandungan kalsium yang tinggi, sehingga dapat dijadikan sebagai alternatif sumber kalsium dari bahan pangan lokal. Berdasarkan penelitian terdahulu, diketahui bahwa jenis pisang raja memiliki kandungan kalsium tertinggi dibandingkan dengan jenis pisang lainnya yaitu $10 \mathrm{mg} / 100$ gram. Buah pisang cenderung memiliki kalori dan kadar protein yang lebih rendah sehingga memerlukan bahan pangan lainnya yang mengandung tinggi kalori dan protein yaitu kacang kedelai. Kandungan kalori dan protein pada 100 gram kacang kedelai berturut-turut adalah 381 kkal dan 40 gram. Selain itu, kacang kedelai juga mengandung tinggi kalsium dimana kandungan kalsium pada kacang kedelai adalah $222 \mathrm{mg} / 100 \mathrm{mg}$ (Candra, 2017).

Salah satu upaya yang dapat dilakukan untuk menambah asupan pada balita adalah memberikan makanan selingan. Selain Air Susu Ibu (ASI) ataupun makanan utama, makanan selingan perlu diberikan untuk membantu memenuhi kebutuhan balita. Kebutuhan balita yang tercukupi dapat mencegah terjadinya stunting (Candra, 2017). Makanan selingan untuk balita yang bergizi dan disajikan dalam bentuk menarik akan membuat anak tertarik untuk mengonsumsinya. Snack bar merupakan salah satu camilan yang cocok untuk dijadikan makanan selingan anak, karena rasanya yang manis, bergizi dan menarik. Pembuatan snack bar dengan mengkombinasikan pisang raja dan kacang kedelai sebagai bahan utama ini diharapkan dapat menghasilkan snack bar dengan kandungan gizi yang bermutu baik dan memiliki tingkat penerimaan yang baik. Adanya proses pengolahan dan pencampuran dengan bahan makanan lainnya dapat menyebabkan perubahan kandungan zat gizi pada snack bar yang dibuat, sehingga perlu dianalisis lebih lanjut kandungan zat gizi, kandungan kalsium dan daya terima snack bar pisang raja dan kacang kedelai.

\section{Bahan dan Metode}

\subsection{Bahan}

Proses pembuatan snack bar dalam penelitian ini menggunakan pisang raja dan kacang kedelai dan bahan lainnya seperti garam, gula pasir, telur dan margarin yang diperoleh dari pasar Srondol, kota Semarang sedangkan susu skim, bubuk cokelat, kismis diperoleh dari toko bahan kue Sumber Rejeki kecamatan Banyumanik kota Semarang. 
Sitasi: Ummah, R., Probosari, E., Anjani, G., \& Afifah, D.N. (2020). Komposisi proksimat, kandungan kalsium dan karakteristik organoleptik snack bar pisang raja dan kacang kedelai sebagai alternatif makanan selingan balita. Warta IHP, 37(2). 162-170

Halaman | 164

\subsection{Alat}

Peralatan yang digunakan dalam penelitian ini adalah mangkuk, sendok, baskom, loyang, oven, timbangan, pisau, nampan, peniris, panci kukus dan spatula.

\subsection{Metode}

Penelitian ini adalah penelitian eksperimental rancangan acak lengkap (RAL) satu faktor dengan perbandingan komposisi pisang raja dan kacang kedelai dalam satuan gram. Formulasi pisang raja dan kacang kedelai disesuaikan dengan syarat selingan yaitu $10 \%$ dari kebutuhan sehari anak balita menurut AKG, protein sebesar $10-20 \%$, lemak sebesar $10-30 \%$ dan karbohidrat sebesar $50-60 \%$ (Sharlin \& Eldestein, 2014). Pada penelitian ini dilakukan 3 taraf perlakuan perbandingan pisang raja dan kacang kedelai yaitu F1 (9:1), F2 (4:1) dan F3 (7:3).

\subsubsection{Pembuatan snack bar}

Tahap pembuatan snack bar diawali dengan pencucian dan perendaman kedelai selama 8 jam, kemudian dikukus dalam suhu $100^{\circ} \mathrm{C}$ selama 20 menit dan dipanggang dalam suhu $127^{\circ} \mathrm{C}$ selama 37 menit (Murugkar, Kotwaliwale, Gupta, Gulati, \& Kumar, 2014; Rahardjo, Bahar, \& Adi, 2019). Selanjutnya, pada tahap pembuatan adonan snack bar, telur dikocok lalu ditambahkan bahan lain seperti gula pasir, garam dan margarin. Kemudian, puree pisang dimasukkan ke dalam adonan, dilanjutkan dengan susu skim dan cokelat bubuk ditambahkan secara bertahap. Kemudian, kismis dan kacang kedelai panggang ditambahkan ke dalam adonan dan diaduk. Setelah itu, adonan dimasukkan ke dalam loyang besi dan dipanggang pada suhu $150^{\circ} \mathrm{C}$ dalam oven selama 30 menit, kemudian snack bar dipotong sama besar dan dipanggang lagi selama 10 menit dalam suhu $150^{\circ} \mathrm{C}$ (Sarifudin, Ekafitri, Surahman, \& Putri, 2015).

\subsubsection{Analisis komposisi proksimat dan kalsium}

Pengujian komposisi proksimat dilakukan dengan 3 kali pengulangan secara duplo yaitu kadar protein dengan metode Kjeldahl, lemak dengan metode Soxhlet, karbohidrat dengan metode by Difference, air dan abu dengan metode gravimetri, serat pangan dengan metode enzimatis dan kalsium dengan metode Spektrofotometri Serapan Atom (SSA) (BSN, 1992; AOAC, 1995).

\subsubsection{Analisis karakteristik organoleptik}

Uji hedonik dengan satu kali pengujian yang diklasifikasikan menjadi 4 skala yaitu 1 = sangat tidak suka, 2 = tidak suka, 3 = suka, dan 4 = sangat suka digunakan untuk menguji daya terima (Fathurrizqiah \& Panunggal, 2015). Uji ini melibatkan 30 mahasiswa Program Studi Ilmu Gizi Fakultas Kedokteran Universitas Diponegoro sebagai panelis semi terlatih (Bakar, 2015).

\subsubsection{Analisis data}

Uji statistik data menggunakan software SPSS. Kandungan gizi berdistribusi normal diuji dengan One Way ANOVA serta uji lanjut Duncan. Apabila kandungan gizi berdistribusi tidak normal dan data daya terima diuji dengan Kruskall-Wallis serta uji lanjut Mann-Whitney (Dahlan, 2013). Metode De Garmo digunakan untuk menentukan formula terbaik (Sapupu, Handayani, \& Rahmi, 2014). Persamaan metode indeks efektifitas dengan prosedur pembobotan yang digunakan sebagai berikut:

$$
\begin{gathered}
\mathrm{NE}=\frac{\mathrm{NP}-\mathrm{NTJ}}{\mathrm{NTB}-\mathrm{NTJ}} \\
\mathrm{NH}=\mathrm{NE} \times \mathrm{BN}
\end{gathered}
$$

Keterangan:

$\mathrm{NE}$ : nilai efektifitas

$\mathrm{NH}$ : nilai hasil

NP : nilai perlakuan

NTJ: nilai terjelek

NTB : nilai terbaik

$\mathrm{BN}$ : bobot nilai

\section{Hasil dan Pembahasan}

\subsection{Kandungan gizi snack bar}

Pada Tabel 1 dan Tabel 2 menunjukkan secara singkat hasil analisis komposisi proksimat dan kalsium snack bar. Kandungan air dan serat pangan tertinggi adalah pada snack bar F1 yang setiap $100 \mathrm{~g}$ memiliki kandungan air 24,30 g dan serat pangan 7,47 g. Kandungan lemak dan karbohidrat tertinggi adalah pada snack bar F2, yang setiap $100 \mathrm{~g}$ memiliki kandungan lemak 12,40 g dan karbohidrat 56,50 g. Pada snack bar F3 setiap $100 \mathrm{~g}$ mengandung 9,36 g protein, 4,02 g abu dan kalsium tertinggi yaitu sebesar $2,66 \mathrm{~g}$. 
Tabel 1

Rerata abu, serat pangan dan kalsium per 100 g snack bar

\begin{tabular}{|c|c|c|c|}
\hline \multirow[b]{2}{*}{ Formula } & \multicolumn{3}{|c|}{ Rerata Kandungan Gizi } \\
\hline & Abu (g) & $\begin{array}{c}\text { Serat } \\
\text { pangan }(g)\end{array}$ & Kalsium (g) \\
\hline F1 (9:1) & $3,54 \pm 0,08^{a}$ & $7,47 \pm 0,14^{a}$ & $1,36 \pm 0,11^{\mathrm{a}}$ \\
\hline F2 $(4: 1)$ & $3,73 \pm 0,09 b$ & $10,20 \pm 0,13^{b}$ & $1,93 \pm 0,06^{b}$ \\
\hline F3 $(7: 3)$ & $4,02 \pm 0,09 \mathrm{c}$ & $12,00 \pm 0,09 \mathrm{c}$ & $2,66 \pm 0,11^{\mathrm{c}}$ \\
\hline & $\mathrm{p}=0,001$ & $\mathrm{p}=0,027$ & $\mathrm{p}=0,000$ \\
\hline
\end{tabular}

Tabel 2

Rerata komposisi protein, lemak, karbohidrat dan air per $100 \mathrm{~g}$ snack bar

\begin{tabular}{|c|c|c|c|c|}
\hline \multirow[b]{2}{*}{ Formula } & \multicolumn{4}{|c|}{ Rerata kandungan gizi } \\
\hline & Protein (g) & Lemak (g) & $\begin{array}{l}\text { Karbohi- } \\
\text { drat (g) }\end{array}$ & $\operatorname{Air}(\mathrm{g})$ \\
\hline F1 (9:1) & $6,77 \pm 0,03^{a}$ & $10,40 \pm 0,12^{\mathrm{a}}$ & $54,80 \pm 0,17^{\mathrm{a}}$ & $24,30 \pm 0,19^{a}$ \\
\hline F2(4:1) & $8,62 \pm 0,03^{b}$ & $12,40 \pm 0,15^{b}$ & $56,50 \pm 0,15^{b}$ & $18,60 \pm 0,29^{b}$ \\
\hline F3(7:3) & $9,36 \pm 0,02^{\mathrm{c}}$ & $11,10 \pm 0,06^{c}$ & $55,20 \pm 0,11^{\mathrm{c}}$ & $20,20 \pm 0,18^{\mathrm{c}}$ \\
\hline & $\mathrm{p}=0,027$ & $\mathrm{p}=0,000$ & $\mathrm{p}=0,0,27$ & $\mathrm{p}=0,000$ \\
\hline
\end{tabular}

Hasil analisis kandungan protein rata-rata sebesar 6,77 - 9,36 g. Penurunan kandungan protein tiap formula snack bar terjadi seiring berkurangnya komposisi kacang kedelai hijau. Proses pemanggangan snack bar menurunkan kandungan protein akibat terjadinya hidrolisis protein dengan adanya proses denaturasi protein pada suhu tinggi dimana terjadi perubahan pada sifat biologis, kimia dan fisik protein sehingga terjadi perubahan pada struktur protein (Ashfiyah, 2019; Eckersall, 2008). Proses pemanasan saat pengolahan menyebabkan terjadinya reaksi Maillard sehingga sebagian protein hilang. Reaksi Maillard dapat terjadi pada pemanggangan dengan suhu di atas $110^{\circ} \mathrm{C}$ (Yu \& Tang, 2016). Reaksi Maillard juga dipengaruhi oleh penggunaan puree pisang matang yang sudah secara alami mengandung gula pereduksi seperti glukosa dan fruktosa yang apabila berikatan dengan asam amino maka terbentuk ikatan silang yang tidak terhidrolisis sehingga terjadi penurunan kadar protein dalam snack bar sehingga terjadi penurunan kadar protein dalam snack bar (Kanaka \& Ayustaningwarno, 2015). Kandungan protein tertinggi terdapat pada snack bar F3 dengan perbandingan pisang raja dan kedelai 70:30 sebesar 9,36 g.

Hasil analisis kandungan lemak memiliki nilai rata-rata 10,40 - 12,40 g. Kandungan lemak tertinggi terdapat pada snack bar F2 dengan perbandingan pisang raja dan kedelai 80:20 sebesar 12,40 g. Kandungan lemak pada snack bar F2 tertinggi disebabkan oleh adanya penguapan kadar air dalam snack bar selama pemanggangan yang dapat meningkatkan kandungan lemak dalam snack bar. Kandungan lemak terendah terdapat pada snack bar F1 dengan perbandingan pisang raja dan kedelai
90:10 sebesar 10,40 g. Proses pemanggangan menggunakan suhu panas dapat menyebabkan kerusakan lemak yang terkandung pada bahan pangan. Hal ini disebabkan oleh lemak yang memiliki sifat mudah menguap tidak tahan panas sehingga lemak apabila dipanaskan bisa mencair bahkan menguap (Kasim, Liputo, Limonu, \& Mohamad, 2018). Semakin tinggi suhu dan lama pemanggangan, maka tingkat kerusakan lemak semakin meningkat. Adanya proses pemanggangan dapat mengubah asam lemak menjadi hidroperoksida yang tidak stabil, sehingga terjadi penurunan kandungan lemak dalam snack bar (Kariada et al., 2014). Adanya penurunan kadar air dapat meningkatkan kandungan bahan solid dalam snack bar (Ashfiyah, 2019). Lemak pada snack bar F1, F2 dan F3 dapat mencukupi kebutuhan makanan selingan balita masing-masing sebesar $75 \%$, $89 \%$ dan $79 \%$. Lemak berperan sebagai simpanan cadangan energi jangka panjang, pembentuk hormon, penyusun otak dan sistem syaraf, serta sebagai pengangkut vitamin larut lemak. Salah satu vitamin larut lemak adalah vitamin $\mathrm{D}$, dimana vitamin $\mathrm{D}$ dalam bentuk aktif berperan dalam mensintesis kalbindin yang berfungsi untuk menyerap kalsium yang sangat mempengaruhi pertumbuhan balita (Azmy \& Mundiastuti, 2018).

Hasil analisis kandungan karbohidrat menunjukkan nilai rata-rata 54,80 - 56,50 g. Seperti halnya lemak, peningkatan karbohidrat dalam snack bar disebabkan oleh adanya penguapan kadar air dalam snack bar selama pemanggangan yang dapat meningkatkan kandungan karbohidrat dalam snack bar (Ashfiyah, 2019). Snack bar F2 mengandung karbohidrat paling tinggi yaitu 56,50 g dengan perbandingan pisang raja dan kedelai 80:20. Hal ini disebabkan oleh adanya kesalahan saat penimbangan kismis sehingga karbohidratnya lebih tinggi dibandingkan formula snack bar lainnya, dimana dalam $100 \mathrm{~g}$ kismis mengandung karbohidrat sebesar 78,47 g (USDA, 2019a). Karbohidrat pada snack bar F1, F2 dan F3 dapat mencukupi kebutuhan makanan selingan balita masing-masing sebesar $94 \%, 97 \%$ dan $94 \%$. Karbohidrat berperan untuk menyuplai energi agar tubuh dapat beraktivitas dan menjaga cadangan lemak dan protein agar tidak dipecah sebagai sumber energi (Whitney \& Rady Rolfes, 2011). Kandungan karbohidrat terendah adalah pada snack bar F1 dengan perbandingan pisang raja dan kedelai 90:10 sebesar $54,8 \mathrm{~g}$.

Hasil analisis kandungan air menunjukkan nilai rata-rata 18,60 - 24,30 g. Kandungan air tertinggi terdapat pada snack bar F1 yaitu sebesar 24,3 g. Tinggi rendahnya kadar air dalam snack bar dapat mempengaruhi rasa, tekstur dan umur simpan. Proses pengolahan dan jenis bahan baku yang digunakan dapat mempengaruhi kandungan kadar 
air snack bar (Lisa, Lutfi, \& Susilo, 2015). Kandungan air dalam 100 gr pisang raja dan kacang kedelai masing-masing sebesar $65,8 \quad \%$ dan $8,54 \quad \%$ (Waspadji, Sukardji, \& Suharyati, 2010; USDA, 2018). Proses pengolahan snack bar yang dilakukan meliputi pengukusan kacang kedelai dan pemanggangan snack bar. Adanya proses pengukusan dapat meningkatkan kadar air melalui proses penyerapan uap air ke dalam snack bar. Kandungan air terendah terdapat pada snack bar F2 dengan perbandingan pisang raja dan kedelai 80:20, yaitu sebesar $18,60 \mathrm{~g}$. Proses pemanggangan dapat menurunkan kadar air dalam snack bar akibat penguapan molekul air selama proses. Kadar air kurang dari $14-15 \%$ pada bahan pangan dapat menghambat pertumbuhan kapang dan jamur penyebab pembusukan. Namun, kadar air dalam snack bar masih tergolong tinggi, sehingga dapat menurunkan umur simpan snack bar (Lisa et al., 2015). Snack bar F2 memiliki kadar air paling rendah, hal ini dapat disebabkan oleh suhu oven yang semakin panas akibat akumulasi panas dari pemanggangan snack bar F1 hingga snack bar F3. Kadar air dalam snack bar menguap oleh panas yang disalurkan melalui oven sehingga kadar air snack bar F2 rendah (Rahmaningsih, Surti, \& Anggo, 2016).

Hasil analisis kandungan abu menunjukkan nilai rata-rata 3,54 - 4,02 g. Adanya proses pembakaran menyebabkan bahan organik habis terbakar, tetapi bahan anorganik atau mineral tidak terbakar. Abu merupakan sisa hasil pembakaran yang tidak terbakar. Kandungan abu dalam suatu bahan pangan dapat menunjukkan kandungan mineral di dalamnya (Kasim et al., 2018). Peningkatan kadar abu disebabkan oleh adanya penurunan kandungan air dalam snack bar yang dapat meningkatkan kadar abu (Aberoumand \& Ziaei-nejad, 2015; Sarastuti \& Yuwono, 2015). Hasil analisis menunjukkan bahwa kandungan abu tertinggi adalah snack bar F3 dengan perbandingan pisang raja dan kedelai 70:30, yaitu sebesar 4,02 g. Hal ini disebabkan oleh semakin tinggi konsentrasi kedelai, maka semakin tinggi kandungan kalsium dalam snack bar, dimana dalam $100 \mathrm{~g}$ kedelai mengandung $222 \mathrm{mg}$ kalsium, sehingga kadar abu juga semakin meningkat (Waspadji et al., 2010). Kandungan abu terendah terdapat pada snack bar F1 dengan perbandingan pisang raja dan kedelai 90:10, yaitu sebesar 3,54 g.

Hasil analisis kandungan serat pangan menunjukkan nilai rata-rata 7,47 - 12,00 g. Pemecahan serat pangan menjadi sejumlah molekul glukosa yang membentuk ikatan polimer $\alpha$ glikosidik menjadi pati resisten sehingga terjadi peningkatan kandungan serat pangan dalam snack bar (Ashfiyah, 2019; Rozali et al., 2018; Setoarto et al., 2015). Hasil analisis menunjukkan bahwa kandungan serat tertinggi adalah snack bar F3 dengan perbandingan pisang raja dan kedelai 70:30, yaitu sebesar 12,00 g. Hal ini disebabkan oleh penggunaan kedelai yang semakin meningkat, sehingga kandungan serat dalam snack bar semakin tinggi, dimana dalam 100 g kedelai mengandung 16,5 g serat (Waspadji et al., 2010). Serat pada snack bar F1, F2 dan F3 dapat mencukupi kebutuhan sebesar $126 \%, 172 \%$ dan $203 \%$. Serat berperan untuk mencegah konstipasi dan obesitas pada anak (Anderson et al., 2009). Kandungan serat pangan terendah terdapat pada snack bar F1 dengan perbandingan pisang raja dan kedelai 90:10, yaitu sebesar 7,47 g.

Hasil analisis kandungan kalsium menunjukkan nilai rata-rata 1360 - 2660 mg. Jika terjadi peningkatan kandungan abu dalam snack bar, maka terjadi pula peningkatan kalsium dalam snack bar karena kandungan abu dapat menunjukkan kandungan mineral pada bahan pangan, salah satunya kalsium (Kasim et al., 2018). Semakin tinggi suhu pemanasan, maka semakin tinggi pula kandungan kalsium dalam bahan pangan (Karimiankhosroshahi et al., 2016). Peningkatan kalsium dalam snack bar disebabkan oleh adanya hidrolisis fitat oleh enzim fitase yang terjadi saat pemanggangan sehingga kemampuan fitat untuk mengikat kalsium menurun dan kalsium dapat lebih mudah diserap tubuh (Satpute \& Annapure, 2013; Hidayat, 2016). Hasil analisis menunjukkan bahwa kandungan kalsium tertinggi adalah pada snack bar F3 dengan perbandingan pisang raja dan kedelai 70:30, yaitu sebesar $2660 \mathrm{mg}$. Hal ini disebabkan oleh semakin tingginya penggunaan kedelai, sehingga kandungan kalsium dalam snack bar semakin tinggi, dimana dalam $100 \mathrm{~g}$ kedelai mengandung $222 \mathrm{mg}$ kalsium (Waspadji et al., 2010). Kandungan kalsium terendah terdapat pada snack bar F1 dengan perbandingan pisang raja dan kedelai 90:10, yaitu sebesar $1360 \mathrm{mg}$.

Kalsium pada snack bar F1, F2 dan F3 dapat memenuhi kebutuhan selingan balita masing-masing sebesar 528 \%, $749 \%$ dan $1026 \%$. Diketahui bahwa kandungan kalsium dalam snack bar melebihi kebutuhan selingan pada balita. Berlebihnya asupan kalsium akan diekskresikan melalui urin. Namun, hal ini tidak menjadi masalah dikarenakan tidak melebihi upper limit kalsium yaitu $2500 \mathrm{mg}$ per hari. Seseorang akan berisiko mengalami batu ginjal yang disebabkan oleh hiperkalsiuria jika mengonsumsi kalsium lebih dari $3000 \mathrm{mg}$ per hari (Cormick \& Belizan, 2019; IOM, 2011). Kalsium berperan dalam pertumbuhan dimana kalsium berkontribusi dalam pembentukan osteoblas dan mineralisasi tulang (Sari et al., 2016). 
Tabel 3

Perkiraan kandungan gizi snack bar per $100 \mathrm{~g}$

\begin{tabular}{lccccc}
\hline Formula & $\begin{array}{c}\text { Pro- } \\
\text { tein } \\
\text { (g) }\end{array}$ & $\begin{array}{c}\text { Lemak } \\
\text { (g) }\end{array}$ & $\begin{array}{c}\text { Karbo- } \\
\text { hidrat } \\
\text { (g) }\end{array}$ & $\begin{array}{c}\text { Serat } \\
\text { pangan } \\
\text { (g) }\end{array}$ & $\begin{array}{c}\text { Kal- } \\
\text { sium } \\
\text { (mg) }\end{array}$ \\
\hline F1 (9:1) & 8,4 & 10,7 & 40,0 & 2,8 & 216,5 \\
F2 (4:1) & 9,4 & 11,2 & 40,3 & 3,0 & 223,1 \\
F3 (7:3) & 10,8 & 11,9 & 40,8 & 3,2 & 231,9 \\
\hline Keterangan: F1 (9:1): Perbandingan pisang raja dan kacang kedelai 90:10 \\
gram; F2 (4:1): Perbandingan pisang raja dan kacang kedelai 80 : 20 gram; \\
F3 (7:3): Perbandingan pisang raja dan kacang kedelai 70:30 gram
\end{tabular}

Tabel 4

Nilai rerata kandungan gizi snack bar

\begin{tabular}{lccccccc}
\hline $\begin{array}{c}\text { Per- } \\
\text { lakuan }\end{array}$ & $\begin{array}{c}\text { Protein } \\
\text { (g) }\end{array}$ & $\begin{array}{c}\text { Le- } \\
\text { mak } \\
\text { (g) }\end{array}$ & $\begin{array}{c}\text { Karbo- } \\
\text { hidrat } \\
\text { (g) }\end{array}$ & $\begin{array}{c}\text { Air } \\
\text { (g) }\end{array}$ & $\begin{array}{c}\text { Abu } \\
\text { (g) }\end{array}$ & $\begin{array}{c}\text { Serat } \\
\text { pangan } \\
\text { (g) }\end{array}$ & $\begin{array}{c}\text { Kal- } \\
\text { sium } \\
\text { (g) }\end{array}$ \\
\hline F1 & 6,77 & 10,40 & 54,80 & 24,3 & 3,54 & 7,47 & 1,36 \\
F2 & 8,62 & 12,40 & 56,50 & 18,6 & 3,73 & 10,20 & 1,93 \\
F3 & 9,36 & 11,10 & 55,20 & 20,2 & 4,02 & 12,00 & 2,66 \\
Rerata & 8,25 & 11,30 & 55,50 & 21,0 & 3,76 & 9,89 & 1,98 \\
\hline
\end{tabular}

Tabel 5

Persen Kecukupan Snack bar Per Sajian (32 g)

\begin{tabular}{lcccccc}
\hline \multirow{2}{*}{ Zat Gizi } & \multicolumn{2}{c}{ Kandungan Gizi Per Bar 32 g } & \multicolumn{3}{c}{$\begin{array}{c}\text { Persen Kecukupan } \\
\text { (\%) }\end{array}$} \\
\cline { 2 - 7 } & F1 & F2 & F3 & F1 & F2 & F3 \\
\hline Protein (g) & 2,17 & 2,76 & 3,00 & 43 & 55 & 60 \\
$\begin{array}{l}\text { Lemak (g) } \\
\text { Karbo- }\end{array}$ & 3,35 & 4,00 & 3,55 & 75 & 89 & 79 \\
$\begin{array}{l}\text { hidrat (g) } \\
\text { Serat } \\
\text { pangan (g) }\end{array}$ & 17,54 & 18,08 & 17,66 & 94 & 97 & 94 \\
$\begin{array}{l}\text { Kalsium } \\
\text { (mg) }\end{array}$ & 2,39 & 3,27 & 3,87 & 126 & 172 & 203 \\
\hline
\end{tabular}

Tabel 6

Kebutuhan Gizi pada Makanan Selingan Balita

\begin{tabular}{lc}
\hline \multicolumn{1}{c}{ Zat Gizi } & Kebutuhan Selingan Balita \\
\hline Protein (g) & 5 \\
Lemak (g) & 4,5 \\
Karbohidrat (g) & 18,7 \\
Serat pangan (g) & 1,9 \\
Kalsium (mg) & 82,5 \\
\hline
\end{tabular}

\subsection{Karakteristik organoleptik snack bar}

Pada Tabel 7 dan Tabel 8 dapat dilihat hasil analisis daya terima snack bar oleh panelis pada parameter warna, rasa, aroma dan tekstur. Berdasarkan uji statistik diketahui bahwa tidak terdapat perbedaan yang signifikan pada warna dan aroma snack bar. Penggunaan bahan-bahan yang sama untuk ketiga perlakuan snack bar menyebabkan hasil uji daya terima untuk warna dan aroma tidak berbeda signifikan berdasarkan penilaian panelis.
Tabel 7

Hasil Analisis Daya Terima Snack bar (1)

\begin{tabular}{|c|c|c|c|c|}
\hline \multirow{2}{*}{ Formula } & \multicolumn{2}{|c|}{ Warna } & \multicolumn{2}{|c|}{ Rasa } \\
\hline & Rerata & Ket & Rerata & Ket \\
\hline $\mathrm{F} 1$ & $3,13 \pm 0,63^{a}$ & Suka & $3,17 \pm 0,70^{\mathrm{ab}}$ & Suka \\
\hline $\mathrm{F} 2$ & $2,93 \pm 0,58^{a}$ & Suka & $3,43 \pm 0,63^{b}$ & Sangat suka \\
\hline \multirow[t]{2}{*}{ F3 } & $3,00 \pm 0,37^{a}$ & Suka & $2,97 \pm 0,67^{a}$ & Suka \\
\hline & \multicolumn{2}{|l|}{$p=0,339$} & $p=0,028$ & \\
\hline \multicolumn{5}{|c|}{$\begin{array}{l}\text { Keterangan: Angka yang diikuti huruf superscript berbeda }(\mathrm{a}, \mathrm{b}, \mathrm{c}) \\
\text { menunjukkan beda nyata }\end{array}$} \\
\hline \multicolumn{5}{|c|}{$\begin{array}{l}\text { Tabel } 8 \\
\text { Hasil Analisis Dava Terima Snack bar (2) }\end{array}$} \\
\hline Perlakuan & Warna & & asa & Aroma \\
\hline F1 & 3,13 & & 16 & 3,40 \\
\hline $\mathrm{F} 2$ & 2,93 & & 43 & 3,30 \\
\hline F3 & 3,00 & & 96 & 3,50 \\
\hline Rerata & 3,02 & & 18 & 3,40 \\
\hline
\end{tabular}

Tabel 9

Nilai Rerata Daya Terima Snack bar

\begin{tabular}{lcccc}
\hline \multirow{2}{*}{ Formula } & \multicolumn{2}{c}{ Aroma } & \multicolumn{2}{c}{ Tekstur } \\
\cline { 2 - 5 } F1 & Rerata & Ket & Rerata & Ket \\
F2 & $3,40 \pm 0,67^{\mathrm{a}}$ & $\begin{array}{c}\text { Sangat } \\
\text { Suka }\end{array}$ & $3,03 \pm 0,85^{\mathrm{a}}$ & Suka \\
F3 & $3,30 \pm 0,84^{\mathrm{a}}$ & $\begin{array}{c}\text { Sangat } \\
\text { Suka }\end{array}$ & $3,43 \pm 0,77^{\mathrm{b}}$ & Sangat Suka \\
& $3,50 \pm 0,51^{\mathrm{a}}$ & $\begin{array}{c}\text { Sangat } \\
\text { Suka }\end{array}$ & $3,00 \pm 0,59^{\mathrm{a}}$ & Suka \\
\hline & $\mathrm{p}=0,818$ & & $\mathrm{p}=0,017$ & \\
\hline
\end{tabular}

Keterangan: Angka yang diikuti huruf superscript berbeda $(\mathrm{a}, \mathrm{b}, \mathrm{c})$ menunjukkan beda nyata

Hasil analisis daya terima snack bar parameter warna memiliki nilai rerata $2,93-3,13$. Snack bar F1 dengan perbandingan pisang raja dan kedelai 90:10 memiliki nilai rerata nilai paling tinggi. Nilai rerata paling rendah adalah snack bar F2 dengan perbandingan pisang raja dan kedelai 80:20. Semua snack bar memiliki tingkat kesukaan pada kategori "suka" serta dapat diterima oleh panelis. Snack bar semua formula mempunyai warna yang hampir sama yaitu cokelat tua sebagai akibat penambahan bubuk cokelat dan terjadinya reaksi Maillard antara gula pereduksi dengan asam amino lisin yang tinggi pada kedelai. Lisin memiliki dua gugus amin yang menyebabkannya lebih reaktif dengan gula pereduksi, sehingga menghasilkan warna cokelat (Pratama \& Ayustaningwarno, 2015).

Hasil analisis daya terima snack bar parameter rasa memiliki nilai rerata 2,97 - 3,43. Snack bar F2 dengan perbandingan pisang raja dan kedelai 80:20 memiliki nilai rerata paling tinggi dengan tingkat kesukaan "sangat suka". Nilai rerata paling rendah adalah snack bar F3 dengan perbandingan pisang raja dan kedelai 70:30. Snack bar F1 dan F3 mempunyai nilai tingkat kesukaan terhadap rasa pada kategori "suka". Rasa semua snack bar disukai panelis karena rasa manisnya. Rasa manis ini berasal dari rasa manis pada pisang, gula pasir dan 
kismis. Kandungan gula dalam 100 gram pisang dan kismis masing-masing adalah $12,23 \mathrm{~g}$ dan $80 \mathrm{~g}$ (USDA 2019a; USDA, 2019b; Schuster et al., 2018).

Hasil analisis daya terima snack bar parameter aroma memiliki nilai rerata 3,30 - 3,50. Snack bar F3 dengan perbandingan pisang raja dan kedelai 70:30 memiliki nilai rerata paling tinggi. Nilai rerata paling rendah adalah snack bar F2 dengan perbandingan pisang raja dan kedelai 80:20. Aroma harum pada snack bar berasal dari gula pasir, susu skim, telur dan pisang. Ketika gula pasir terkena panas akan berubah menjadi karamel. Adanya senyawa maltol dan isomaltol pada proses karamelisasi inilah yang membuat adanya aroma harum karamel yang kuat pada snack bar (Yanto, Karseno, \& Purnamasari, 2015). Susu skim menimbulkan aroma wangi karena adanya kandungan laktosa dalam susu skim (Alsuhaibani, 2018). Telur memproduksi senyawa pirazin yang menimbulkan aroma khas wangi dan enak saat dipanggang (Imami \& Sutrisno, 2018). Pisang juga memiliki aroma kuat sebagai bahan utama pada pembuatan makanan. Hal ini dikarenakan pisang mengandung senyawa volatil yaitu isoamil eter yang menimbulkan aroma kuat (Yanto et al., 2015). Kedelai dalam snack bar tidak menyebabkan timbulnya aroma langu. Hal ini dikarenakan saat proses persiapan kedelai, kedelai dikukus terlebih dahulu selama 20 menit untuk menginaktivasi enzim lipoksigenase yang menyebabkan langu, sehingga dengan terinaktivasinya enzim tersebut dapat mengurangi timbulnya bau langu dari kedelai (El-Shemy, 2011).

Hasil analisis daya terima tekstur snack bar menunjukkan nilai rerata 3,00 - 3,43. Snack bar F2 dengan perbandingan pisang raja dan kedelai 80:20 memiliki nilai rerata paling tinggi. Nilai rerata paling rendah adalah snack bar F3 dengan perbandingan pisang raja dan kedelai 70:30. Snack bar F2 paling disukai panelis dengan tingkat kesukaan "sangat suka", sedangkan, snack bar F1 dan F3 dengan tingkat kesukaan "suka". Parameter tekstur menunjukkan perbedaan pada snack bar F1 dan F2 serta snack bar F2 dan F3. Tekstur yang paling disukai oleh panelis adalah snack bar F2. Hal ini

Tabel 10

Formula Snack bar Terbaik

\begin{tabular}{|c|c|c|c|c|c|c|c|c|c|c|}
\hline \multirow{2}{*}{ Parameter } & \multirow{2}{*}{ B.V } & \multirow{2}{*}{ B.N } & \multicolumn{2}{|c|}{ F1 } & \multicolumn{2}{|c|}{ F2 } & \multicolumn{2}{|c|}{ F3 } & \multirow{2}{*}{ Terbaik } & \multirow{2}{*}{ Terjelek } \\
\hline & & & N.E & N.H & N.E & N.H & N.E & N.H & & \\
\hline Protein & 1,00 & 0,08 & 0,00 & 0,00 & 0,71 & 0,06 & 1,00 & 0,08 & 9,36 & 6,77 \\
\hline Lemak & 1,37 & 0,11 & 0,00 & 0,00 & 1,00 & 0,11 & 0,35 & 0,04 & 12,40 & 10,40 \\
\hline Karbohidrat & 6,73 & 0,53 & 0,00 & 0,00 & 1,00 & 0,53 & 0,24 & 0,12 & 56,50 & 54,80 \\
\hline Air & 0,25 & 0,02 & 1,00 & 0,02 & 0,00 & 0,00 & 0,28 & 0,01 & 2,02 & 1,86 \\
\hline $\mathrm{Abu}$ & 0,46 & 0,04 & 0,00 & 0,00 & 0,40 & 0,01 & 1,00 & 0,04 & 4,02 & 3,54 \\
\hline Serat pangan & 1,20 & 0,09 & 1,00 & 0,09 & 0,00 & 0,00 & $-0,66$ & $-0,06$ & 7,47 & 10,20 \\
\hline Kalsium & 0,24 & 0,02 & 0,00 & 0,00 & 0,44 & 0,01 & 1,00 & 0,02 & 2,66 & 1,36 \\
\hline Warna & 0,37 & 0,03 & 1,00 & 0,03 & 0,00 & 0,00 & 0,35 & 0,01 & 3,13 & 2,93 \\
\hline Rasa & 0,39 & 0,03 & 0,43 & 0,01 & 1,00 & 0,03 & 0,00 & 0,00 & 3,43 & 2,96 \\
\hline Aroma & 0,41 & 0,03 & 0,50 & 0,02 & 0,00 & 0,00 & 1,00 & 0,03 & 3,50 & 3,30 \\
\hline Tekstur & 0,38 & 0,03 & 0,07 & 0,00 & 1,00 & 0,03 & 0,00 & 0,00 & 3,43 & 3,00 \\
\hline Total & 4,70 & & & 0,30 & & 0,55 & & 0,54 & & \\
\hline
\end{tabular}

Keterangan: BV = Bobot Variabel ; BN = Berat Normal ; N.E = Nilai Efektivitas ; N.H = Nilai Hasil disebabkan tekstur pada snackbar F2 tidak terlalu keras dan tidak terlalu lunak. Semakin banyak kadar pisang pada snack bar menyebabkan tekstur snack bar menjadi lunak dan semakin banyak kadar kedelai pada snack bar menyebabkan snack bar menjadi keras. Hal ini disebabkan dalam 100 gram pisang raja mengandung air sebesar 65,8 \% (Waspadji et al., 2010).

\subsection{Formulasi snack bar terbaik}

Hasil analisis formula terbaik menggunakan metode De Garmo dapat dilihat pada Tabel 10. Hasil tersebut menunjukkan bahwa snack bar dengan formula terbaik dapat dilihat dari kandungan gizi dan daya terimanya, yaitu snack bar F2 dengan perbandingan pisang raja dan kedelai 80 : 20 dengan Nilai Hasil (NH) sebesar 0,55. Oleh sebab itu, snack bar yang direkomendasikan adalah snack bar F2. Sebagian besar kandungan gizi dalam snack bar F2 dapat memenuhi kebutuhan makanan selingan balita. Kandungan gizi tersebut adalah lemak $4 \mathrm{~g}$, karbohidrat 18,08 g, serat pangan 3,27 g dan kalsium 617,6 mg. Selain itu, daya terima snack bar F2 dari segi rasa, aroma dan tekstur pada tingkat kesukaan "sangat suka".

Makanan selingan (snack) adalah suatu produk yang biasanya dikonsumsi di antara waktu makan utama. Snack biasa dikonsumsi dengan jangka waktu 2-3 jam sebelum makanan utama dikonsumsi (kecuali sarapan) yang berkontribusi antara 10-20\% dari kalori kebutuhan total. Snack sangat digemari oleh semua kalangan baik anak-anak maupun orang dewasa. Adanya makanan selingan berfungsi untuk menambah zat gizi yang kurang diperoleh pada saat makan utama. Makanan selingan tidak bisa menggantikan waktu makan utama karena jumlah kalori yang rendah. Marangoni et al (2019) menyebutkan syarat makanan selingan anak yaitu memberikan kalori dan zat gizi yang cukup, mudah dicerna dan tidak merangsang alat cerna, diberikan dalam waktu yang tidak dekat dengan waktu makan, 
disajikan semenarik mungkin, dan menghindari makanan selingan rendah zat gizi (contohnya keripik). Selain itu, Florida Department of Health (2013) menekankan bahwa makanan selingan juga harus memiliki warna yang menarik, rasa yang enak, bau yang sedap dan tekstur yang mudah dikunyah oleh anak.

\section{Kesimpulan}

Perbedaan formula snack bar berpengaruh signifikan $(p<0,05)$ terhadap kandungan gizi, daya terima dari segi rasa dan tekstur, namun tidak memberikan pengaruh signifikan pada parameter warna dan aroma $(p>0,05)$. Formula terbaik adalah snack bar F2 dengan kandungan lemak $4 \mathrm{~g}$, karbohidrat $18,08 \mathrm{~g}$, serat pangan $3,27 \mathrm{~g}$ dan kalsium $617 \mathrm{mg}$.

\section{Ucapan Terima Kasih}

Penulis mengucapkan terima kasih kepada semua pihak yang terlibat dalam membantu kelancaran penelitian ini.

\section{Daftar Pustaka}

Aberoumand, A. \& Ziaei-nejad, S. (2015). Effect of Cooking on Quality Commonly Consumed Marine Fish Platycephalidae (Platycephalus indicus) in Iran. Turkish Journal of Agriculture, 3(11), 891-893.

Alsuhaibani, A. M. A. (2018). Rheological and Nutritional Properties and Sensory Evaluation of Bread Fortified with Natural Sources of Calcium. Journal of Food Quaity, 2018, 1-7.

Anderson, J.W., Baird, P., Jr, R.H.D., Ferreri, S., Knudtson, M., Koraym, A. et al. (2009). Health benefits of dietary fiber. Nutrition, 67(4), 188205.

AOAC. (1995). Official Methods of Analysis, 16th Edition, Washington DC; AOAC International.

Ashfiyah, V.N. (2019). Substitusi Sorgum dan Ubi Jalar Putih pada Roti Bagel sebagai Alternatif Selingan untuk Penderita Diabetes. Media Gizi Indonesia, 14(1), 75-86.

Azmy, U. \& Mundiastuti, L. (2018). Konsumsi Zat Gizi pada Balita Stunting dan Non- Stunting di Kabupaten Bangkalan. Amerta Nutrition, 2(3),292-298.

Bakar, B. (2015) Tata Laksana Uji Organoleptik Nasi. Aceh: Balai Pengkajian Teknologi Pertanian Aceh.

BSN (Badan Standardisasi Nasional). (1992). SNI 012891-1992 : Cara Uji Makanan dan Minuman. Jakarta.

Candra, A. (2017). Suplementasi Mikronutrien dan Penanggulangan Malnutrisi pada Anak Usia di Bawah Lima Tahun (Balita). Diponegoro
Journal of Nutrition and Health, 5(3), 159165.

Cormick, G. \& Belizan, J. M. (2019). Calcium Intake and Health. Nutrients, 11(1606), 1-16.

Dahlan, M.S. (2013). Statistik untuk Kedokteran dan Kesehatan, Edisi 5. Jakarta: Salemba Medika.

Eckersall, P. D. (2008). Proteins, Proteomics, and the Dysproteinemias. In: Clinical Biochemistry of Domestic Animals (6th ed.). London: Elsevier Inc.

El-Shemy, H. A. (2011). Soybean and Health. Croatia: InTech.

Esfarjani, F., Roustaee, R., Mohammadi-Nasrabadi, F. \& Esmaillzadeh A. (2013). Major Dietary Patterns in Relation to Stunting among Children in Tehran, Iran. Journal of Health, Population and Nutrition, 31(2), 202-210.

Fathurrizqiah, R. \& Panunggal, B. (2015). Kandungan Pati Resisten, Amilosa, dan Amilopektin Snack bar Sorgum sebagai Alternatif Makanan Selingan Bagi Penderita Diabetes Melitus Tipe 2. Jornal of Nutrition College, 4(2), 562-569.

Florida Department of Health. (2013). Nutrition and Menu Planning for Children in the Child Care Food Program. Florida: The University North Carolina.

Hidayat, C. (2016). Pemanfaatan Fitase sebagai Upaya Penanggulangan Asam Fitat dalam Ransum Ayam Pedaging. Jurnal Wartazoa, 26(2), 57-68.

Imami, R. H. \& Sutrisno, A. (2018). Pengaruh Proporsi Telur dan Gula serta Suhu Pengovenan terhadap Kualitas Fisik, Kmia dan Organoleptik pada Bolu Bebas Gluten dari Pasta Ubi Kayu (Manihot Esculenta). Jurnal Pangan dan Agroindustri, 6(3), 89-99.

IOM (Institute of Medicine). (2011). Dietary Reference Intakes for Calcium and Vitamin D. Ross AC, Taylor CL, Yaktine AL, Valle HB Del (Ed.). Washington DC: The National Academies Press.

Kanaka, D. A. \& Ayustaningwarno, F. (2015). Nilai Cerna Protein In-Vitro Biskuit dengan Substitusi Kecambah Kedelai (Glycine max L. Merril) dan Pisang (Musa paradisiaca sp) sebagai Makanan Sehat untuk Anak Sekolah Dasar. Journal of Nutrition College, 4(2), 141146.

Kariada, N., Martuti, T., Rosidah. \& Saputro, D. D. (2014). Oven Panggang sebagai Solusi Pengolahan Ikan Higienis dan Ramah Lingkungan. Rekayasa, 12(2), 1-9.

Karimian-khosroshahi, N., Hosseini, H., Rezaei, M., Khasksar, R. \& Mahmoudzadeh, M. (2016). Effect of Different Cooking Methods on Minerals, Vitamins, and Nutritional Quality Indices of Rainbow Trout (Oncorhynchus mykiss). International Journal of Food Properties, 19(11), 2471-80. 
Sitasi: Ummah, R., Probosari, E., Anjani, G., \& Afifah, D.N. (2020). Komposisi proksimat, kandungan kalsium dan karakteristik organoleptik snack bar pisang raja dan kacang kedelai sebagai alternatif makanan selingan balita. Warta IHP, 37(2). 162-170

Halaman | 170

Kasim, R., Liputo, S.A., Limonu, M. \& Mohamad, F.P. (2018). Pengaruh Suhu dan Lama Pemanggangan terhadap Tingkat Kesukaan dan Kandungan Gizi Snack Food Bars Berbahan Dasar Tepung Pisang Goroho dan Tepung Ampas Tahu. Jurnal Technopreneur, 6(2), 41-48.

Kementerian Kesehatan RI. (2010). SK Antropometri Penilaian Status Gizi Anak. Jakarta.

Kementerian Kesehatan RI. (2018). Situasi Balita Pendek (Stunting) di Indonesia. Jakarta.

Lisa, M., Lutfi, M. \& Susilo B. (2015). Pengaruh Suhu dan Lama Pengeringan terhadap Mutu Tepung Jamur Tiram Putih (Plaerotus ostreatus). Jurnal Keteknikan Pertanian Tropis dan Biosistem, 3(3), 270-279.

Marangoni, F., Martini, D., Scaglioni, S., Sculati, M., Donini, L. M., Leonardi, F. et al. (2019). Snacking in Nutrition and Health. International Journal of Food Sciences and Nutrition, 70(8), 909-923.

Murugkar, D.A., Kotwaliwale, N., Gupta, C., Gulati, P. \& Kumar, M. (2014). Optimization of SoyButter from Sprouted Soybean and Its Quality Parameters. Journal of Food Quality, 37, 63-72.

Persagi (Persatuan Ahli Gizi Indonesia). (2017). Tabel Komposisi Pangan Indonesia. Jakarta: Elex Media Komputindo.

Pratama, S. H. \& Ayustaningwarno, F. (2015). Kandungan Gizi, Kesukaan dan Warna Biskuit Substitusi Tepung Pisang dan Kecambah Kedelai. Journal of Nutrition College, 4(2), 252-258.

Rahardjo, L. J., Bahar, A. \& Adi, A. C. (2019). Pengaruh Kombinasi Kacang Kedelai ( Glycine Max ) dan Kacang Tunggak ( Vigna Unguiculata ( L ) Walp .) yang Diperkaya Biji Nangka ( Artocarpus Heterophyllus ) Terhadap Daya Terima dan Kadar Protein Snack bar. Amerta Nutrition, 3(1), 71-77.

Rahmaningsih, A., Surti, T. \& Anggo, A. D. (2016). Pengaruh Penambahan Tepung Lindur (Bruguiera gymnorrhiza) terhadap Kualitas Biskuit Ikan Lele (Clarias batrachus). Jurnal Pengolahan dan Bioteknologi Hasil Perikanan, 5(3), 52-59.

Rozali, Z. F., Purwani, E. Y., Iskandriati, D., Palupi, N. S. \& Suhartono, M.T. (2018). Potensi Pati Resisten Beras sebagai Bahan Pangan Fungsional. Jurnal Pangan, 27, 215-224.

Sapupu, E. E. B., Handayani, D. \& Rahmi, Y. (2014). Pengaruh Substitusi Tepung Terigu dengan Tepung Daun Turi (Sesbania grandiflora) terhadap Mutu Daging Nabati. Indonesian Journal of Human Nutrition, 1(2), 114-127.

Sarastuti, M. \& Yuwono, S. S. (2015). Pengaruh Pengovenan dan Pemanasan terhadap SifatSifat Bumbu Rujak Cingur Instan Selama Penyimpanan. Jurnal Pangan dan
Agroindustri, 3(2), 464-475.

Sari, E. M., Juffrie, M., Nurani, N. \& Sitaresmi, M. N. (2016). Asupan Protein, Kalsium dan Fosfor pada Anak Stunting dan Tidak Stunting Usia 24-59 Bulan. Jurnal Gizi Klinik Indonesia, 12(4), 152-159.

Sarifudin. A., Ekafitri, R., Surahman, D. N. \& Putri, S. K. D. F. A. (2015). Pengaruh Penambahan Telur pada Kandungan Proksimat, Karakteristik Aktivitas Air Bebas (Aw) dan Tekstural Snack bar Berbasis Pisang (Musa paradisiaca). Jurnal Agritech, 35(01), 1-8.

Satpute, M. \& Annapure, U. (2013). Approaches for Delivery of Heat Sensitive Nutrients through Food Systems for Selection of Appropriate Processing Techniques: A Review. Journal of Hygienic Engineering and Design, 4,71-92.

Schuster, M. J., Wang, X., Hawkins, T. \& Painter, J. E. (2018). A Comprehensive Review of Raisins and Raisin Components and Their Relationship to Human Health. Journal of Nutrition and Health, 50(3), 203-216.

Sharlin, J. \& Eldestein, L. (2014). Gizi Normal pada Todler Hingga Usia Sekolah dan Peran Orang Tua dalam Meningkatkan Gizi yang Sehat pada Masa Kanak-Kanak Awal. In: Buku Ajar Gizi dalam Daur Kehidupan. Jakarta: EGC.

USDA. (2018). National Nutrient Data Base for Standard. Basic Report 16108, Soybeans, mature seeds, raw. The National Agriculutural Library.

USDA. (2019a). National Nutrient Data Base for Standard. Full Report ( All Nutrients ) 09299, Raisins, seeded. The National Agriculutural Library.

USDA. (2019b). National Nutrient Data Base for Standard. Full Report (All Nutrients) 09040, Bananas, raw Report. The National Agriculutural Library.

Waspadji, S., Sukardji, K. \& Suharyati. (2010). Daftar Bahan Makanan Penukar (3rd ed.). Jakarta: Balai Penerbit Fakultas Kedokteran Universitas Indonesia.

Whitney. E. \& Rady Rolfes, S. (2011). Understanding Nutrition (12th ed.). Williams $P$, Rose N, Feldman E, Tarson L (Ed.). Medicine. United States of America: Wadsworth, Cengage Learning.

Yanto, T., Karseno. \& Purnamasari, M.M.D. (2015). Pengaruh Jenis dan Konsentrasi Gula terhadap Karakteristik Fisikokimia dan Sensori Jelly Drink. Jurnal Teknologi Hasil Pertanian, 8(2), 123-129.

Yu, A-N. \& Tang, L-P. (2016). Kinetics of NonEnzymatic Browning Reaction from the lAscorbic Acid / L-Cysteine Model System. Czech Journal of Food Sciences, 34(6), 503510. 